\title{
MODEL PENYEBARAN PENYAKIT MENINGITIS PADA MUSIM HAJI DI MADINAH DAN MEKKAH
}

\author{
Norisca Lewaherilla ${ }^{1,2}$, Fransiska A. A. P. Maitimu ${ }^{2}$, Cukri Rahmi Niani ${ }^{3}$ \\ ${ }^{1}$ Jurusan Matematika Fakultas Matematika dan Ilmu Pengetahuan Alam, Universitas Pattimura \\ ${ }^{2}$ Jurusan Teknik Industri Fakultas Teknik, Universitas Pattimura \\ ${ }^{3}$ Jurusan Teknik Sipil Fakultas Teknik, Universitas Teuku Umar \\ e-mail: lewaherillanorisca@gmail.com, cicamaitimu25@gmail.com
}

\begin{abstract}
Abstrak
Kegiatan haji dan umrah tahunan di Arab Saudi sangat berisiko terjadinya penyebaran bakteri gram negatif Neisseria meningitidis, yang mengakibatkan penyakit meningitis. Bakteri bisa saja terbawa oleh orang-orang yang berasal dari negara endemik maupun epidemik meningitis, dan ditularkan melalui interaksi dari kumpulan orang yang bersama-sama melakukan ibadah haji maupun umrah. Model penyebaran penyakit ini dilakukan dengan membandingkan kasus sebelum dan sesudah aturan vaksinasi dilakukan pada dua periode untuk jamaah dari negara kecil dan negara besar. Periode pertama adalah saat jamaah haji masih berada di Madinah, sedangkan periode kedua saat jamaah haji melakukan aktifitas bersama di Mekkah dan kembali ke Madinah menanti kepulangan. Hasil simulasi data menunjukkan bahwa banyak atau sedikitnya jamaah yang terinfeksi sangat mempengaruhi kecepatan laju penyebaran meningitis yang tertular melalui kontak langsung.
\end{abstract}

Kata Kunci: Aturan vaksinasi, haji, meningitis, model penyebaran

\section{TRANSMISSION MODEL OF MENINGITIS DISEASE IN HAJJ SEASON IN MEDINA AND MECCA}

\begin{abstract}
The annual Hajj and Umrah activity in Saudi Arabia is very risky for the spread of Neisseria meningitidis gram negative bacteria, resulting meningitis. Bacteria may be carried by people from both endemic and epidemic countries of meningitis, and is transmitted through the interaction of a group of people who together perform the pilgrimage or umrah. The model of the spread of the disease is done by comparing cases before and after the vaccination rule is done in two periods for pilgrims from small countries and large countries. The first period is when pilgrims are still in Madinah, while the second period when pilgrims perform joint activities in Mecca and return to Madina awaits return. The results of data simulation show that many or at least infected pilgrims strongly influence the rate of spread of meningitis that is transmitted through direct contact.
\end{abstract}

Keywords: dispersion model, hajj, meningitis, vaccination rule.

\section{Pendahuluan}

Perjalanan haji adalah perjalanan yang dilakukan oleh umat muslim ke Arab Saudi yaitu ke MekkahMadinah untuk melakukan ibadah haji. Sekitar 2 juta umat muslim di dunia melakukan ibadah secara serentak yaitu pada bulan Zulhijjah. Hal ini yang menyebabkan penyakit meningitis sangat mudah terjangkit pada para jamaah haji. Pada tahun 1987 dan 2000 terjadi kejadian luar biasa meningitis meningikokus yang menimpa para jamaah haji di Arab Saudi, yang merupakan negara epidemis terjadinya penyakit meningitis. Pada tahun 1987, terdapat sekitar 99 kasus meningitis meningokokus yang menimpa jamaah haji Indonesia dan 40 diantaranya meninggal dunia. Oleh karena itu, Kementrian kesehatan Kerajaan Arab Saudi, sejak tahun 2002 telah mewajibkan negara-negara yang mengirimkan jamaah haji untuk memberikan vaksinasi meningitis sebagai syarat pokok pemberian visa haji dan umrah dalam upaya pencegahan penularan meningitis. Tindakan pencegahan penyakit meningitis pada kegiatan haji dan umrah saat ini tidak serta merta 
mencegah terbawa dan tertularnya bakteri, yang dapat menyebabkan wabah lokal dan internasional di antara populasi yang rentan. [1].

Para jamaah haji dari masing-masing negara akan melaksanakan ibadah haji secara serentak yaitu dari tanggal 1-10 zulhijjah. Sebanyak 2 juta umat Muslim terlibat dalam kondisi kontak langsung jamaah lain. Hal ini merupakan peluang besar untuk penyakit meningitis tertular.

Tujuan penulisan ini yaitu untuk membandingkan laju penularan penyakit meningitis pada jamaah haji sebelum dan sesudah penggunaan vaksin dengan memperhatikan interaksi antara jamaah haji yang berasal dari negara besar dengan negara kecil. Fokus dalam penulisan ini adalah melihat penyebaran dinamis dari infeksi meningitis dari satu individu ke individu lain dalam populasi jamaah yang melakukan ibadah haji di Madinah dan Mekkah.

\section{Metodologi Penelitian}

\subsection{Meningitis di Musim Haji}

Moribiditas dan mortalitas yang cukup signifikan di seluruh dunia disebabkan oleh penyakit meningitis dalam bentuk endemik maupun epidemik. Wabah meningitis tercatat puluhan tahun sebelum penemuan agen penyebabnya. Banyak epidemik terjadi di Eropa dan Amerika pada tahun 1837-1887. Penyakit meningitis adalah penyakit yang menyerang saluran pernafasan dan mengakibatkan meningitis. Meningitis mengakibatkan peradangan selaput otak dan saraf punggung, dan/atau septisemia (keracunan darah). Penderita penyakit meningitis dapat dengan sangat cepat jatuh sakit parah.

Meningitis umumnya berasal dari infeksi virus dan bakteri yang ditularkan saat batuk, bersin, ciuman, dan berbagi makanan dengan sendok yang sama, pemakaian sikat gigi yang sama dan merokok bergantian dalam satu batang. Meningitis dapat disebabkan oleh mikroorganisme, kanker, luka fisik dan juga obatobatan. Jika anda telah tertular penyakit ini maka anda akan beresiko menjadi carrier, dan infeksius. Masa inkubasi penyakit ini rata-rata 3-4 hari sampai gejalanya terlihat. Penyakit ini umumnya terjadi 1-14 hari setelah paparan dan muncul sebagai meningitis pada $\geq 50 \%$ kasus. Gejala penyakit meningitis tidak spesifik tetapi mungkin termasuk demam, sakit kepala, kekejangan leher, sakit sendi, ruam dengan bintik atau lebam ungu, kurang senang dengan cahaya cerah, dan muntah secara mendadak. Penyakit meningitis invasif tetap merupakan masalah kesehatan masyarakat yang serius yang mempengaruhi hingga 1,2 juta orang setiap tahunnya dan menyebabkan antara 50.000 dan 135.000 kematian di seluruh dunia. Bahkan dengan pengobatan yang tepat, tingkat kematian kasusnya tinggi, dan risiko penularan infeksi meningitis jangka panjang menambah beban penyakit, terutama di negara-negara berkembang.

Ibadah haji dan umrah adalah salah satu pertemuan massal terbesar dan paling geografis dari beragam etnis di dunia. Setiap umat Muslim dewasa bertubuh sehat yang mampu melakukannya diharuskan untuk membuat haji setidaknya sekali dalam hidupnya. Haji dilakukan pada bulan ke 12 kalender Islam (lunar) selama beberapa hari dan menarik lebih dari dua juta Muslim dari lebih 183 negara ke Arab Saudi setiap tahunnya. Mekkah juga merupakan lokasi untuk ritual yang relatif lebih kecil yang disebut Umrah, yang dilakukan sepanjang tahun. Ini melibatkan ritual yang berbeda dengan haji dan dilakukan dalam periode waktu yang lebih singkat. Peningkatan perjalanan internasional telah membuat Umrah sangat sesak, terutama dalam 3 bulan sebelum haji ketika jumlah peziarah saingan haji. Meskipun bukan bagian penting dari haji atau umrah, banyak peziarah juga pergi ke Madinah, utara Mekkah, sebagai bagian dari haji mereka. Kelelahan fisik, cuaca panas yang ekstrem, dan akomodasi yang padat, memungkinkan penularan penyakit selama pertemuan massal ini, termasuk penyakit meningitis. Lebih lanjut mengenai perkembangan penyebaran penyakit meningitis dari sebelum tahun 1990, tahun 2000 hingga sekarang, serta meningitis pada musim haji dapat dibaca lebih lanjut pada [2].

\subsection{Model Penyebaran Penyakit [3].}

Model penyebaran penyakit dilakukan dengan mengelompokkan individu menjadi kompartemen berdasarkan variabel keadaan tunggal dan diskrit. Kompartemen disebut kompartemen penyakit jika individu di dalamnya terinfeksi.. Penyakit yang memberi kekebalan memiliki struktur kompartemen yang berbeda dari penyakit tanpa imunitas dan penyakit yang ditularkan oleh vektor. Tingkat transfer antar kompartemen dinyatakan secara matematis sebagai turunan sehubungan dengan waktu ukuran kompartemen. Model diformulasikan pada dalam persamaan diferensial. Model dengan tingkat transfer bergantung pada ukuran 
kompartemen selama masa lalu dan pada saat transfer menghasilkan tipe persamaan fungsional yang lebih umum, seperti persamaan diferensial dan persamaan integral. Model kompartemen pada tulisan ini dibagi menjadi empat kompartemen.

Secara umum, untuk memodelkan penyebaran penyakit meningitis yang tergolong epidemis, maka populasi yang diteliti dibagi ke dalam tiga kelas yang diberi label $S, I$ dan $R . S(t)$ menyatakan jumlah individu yang rentan terhadap penyakit ini, yaitu, yang belum terinfeksi pada waktu $t$. $I(t)$ menyatakan jumlah individu yang terinfeksi, dianggap menular dan mampu menyebarkan penyakit ini melalui kontak dengan suseptibilitas (susceptibles). $R(t)$ menyatakan jumlah individu yang telah terinfeksi dan kemudian dikeluarkan dari kemungkinan terinfeksi lagi atau penyebaran infeksi. Penghapusan dilakukan melalui isolasi dari populasi lainnya, melalui imunisasi terhadap infeksi, melalui pemulihan dari penyakit ini dengan kekebalan penuh terhadap infeksi ulang, atau melalui kematian akibat penyakit ini. Pada tulisan ini, proses tersebut ditandai dengan aturan vaksinasi.

Selain perbedaan dasar antara penyakit dimana pemulihan memberikan kekebalan terhadap infeksi ulang dan penyakit dimana anggota yang sembuh rentan terhadap infeksi ulang, dan kemungkinan menengah kekebalan sementara yang ditandai dengan model tipe $S I R S$, diperlukan struktur kompartemen yang lebih rumit. Misalnya, model SEIR yang digunakan pada tulisan ini. Variabel independen dalam model kompartemen yang digunakan dalam waktu $t$, dan tingkat transfer antar kompartemen dinyatakan secara matematis sebagai turunan sehubungan dengan waktu ukuran kompartemen.

Proses epidemis diasumsikan bersifat deterministik, yaitu bahwa perilaku suatu populasi ditentukan sepenuhnya oleh sejarahnya dan oleh aturan yang menggambarkan model tersebut. Dalam merumuskan model turunan untuk masing-masing kompartemen, diasumsikan bahwa jumlah anggota dalam kompartemen adalah fungsi waktu yang terdiferensialkan. Pada banyak penyakit menular, ada periode yang terpapar setelah penularan infeksi dari suseptibilitas ke anggota yang berpotensi infektif tapi sebelum potensi infeksi ini mengembangkan gejala dan dapat menularkan infeksi. Untuk memasukkan periode terpapar dengan periode terpapar rata-rata $1 / \kappa$, maka ditambahkan kompartemen $E$ yang terpapar dan menggunakan kompartemen $S, E, I, R$ dan jumlah populasi total $N=S+E+I+R$ untuk memberikan generalisasi epidemis. Secara umum model sederhananya dinyatakan sebagai berikut,

$$
S^{\prime}=-\beta S I \quad \operatorname{dan} I^{\prime}=(\beta S-\alpha) I
$$

dengan initial condition:

$$
S(0)=S_{0}, \quad I(0)=I_{0}, \quad S_{0}+I_{0}=N
$$

Model SEIR secara umum adalah sebagai berikut.

$$
S^{\prime}=-\beta S I, \quad E^{\prime}=(\beta S I)-\kappa E, \quad \text { dan } I^{\prime}=\kappa E-\alpha I
$$

\subsection{Aturan Vaksinasi}

Vaksin meningitis ini diberikan bagi calon jamaah haji untuk mencegah bakteri meningitis yang masih menjadi endemis di beberapa negara. Umumnya dikenal dengan African Meningitis Belt yang berasal dari daerah sub-sahara Afrika. Untuk mencegahnya, vaksin meningitis menjadi imunisasi yang diwajibkan oleh Kementerian Kesehatan Arab Saudi. Sertifikat yang menyatakan bahwa mereka telah mendapat imunisasi meningitis menjadi syarat bagi calon haji untuk mendapatkan visa.

\section{Hasil dan Pembahasan}

\subsection{Asumsi-asumsi Pemodelan Matematika yang Digunakan}

1) Pada periode pertama saat jamaah haji masih berada di Madinnah, tidak terjadi interaksi warga negara satu negara dengan warga negara lain karena masih tinggal di pemondokkan terpisah.

2) Tidak terjadi kelahiran dan kematian alami selama kegiatan haji.

3) Interaksi jemaat antar warga negara terjadi pada periode kedua, dimana jamaah haji melakukan aktifitas bersamaan di Mekkah dan kembali ke Madinah menanti kepulangan. 
4) Dimodelkan interaksi antar jemaat yang berasal dari satu negara besar dan jemaat dari satu negara kecil pada periode kedua saat jamaah berada di Mekkah dan Madinah (saat menanti kepulangan ke negara asal).

\subsection{Daftar Notasi}

$d S b$ : laju penularan meningitis pada negara besar

$d S k$ : laju penularan meningitis pada negara kecil

$\lambda \quad$ : peluang penularan ke jamaah sehat

$I_{b}$ : populasi infeksi pada negara besar; $I_{k}$ : populasi infeksi pada negara kecil

$S_{b}$ : populasi sehat negara besar; $S_{k}$ : populasi sehat negara kecil

$N_{b}$ : populasi negara besar yang melakukan ibadah haji

$N_{k}$ : populasi negara kecil yang melakukan ibadah haji

$\gamma_{b}$ : peluang jamaah terinfeksi

$\tau_{b}$ : peluang pemulihan penderita dari negara besar

$\tau_{k}$ : peluang pemulihan penderita dari negara kecil

$\alpha$ : presentasi vaksin; $\omega$ : peluang vaksin gagal

$S_{b v}$ : populasi negara besar yang tervaksin; $S_{k v}$ : populasi negara kecil yang tervaksin

$E_{b v}$ : populasi negara besar yang tertular tapi menerima vaksin

$E_{k v}$ : populasi negara kecil yang tertular tapi menerima vaksin

\subsection{Pemodelan Tanpa Aturan Vaksinasi}

\subsubsection{Kasus Periode 1}

Jamaah haji yang datang dari berbagai negara singgah di Madinnah selama 7 hari untuk menanti rombongan lain agar dapat bersama-sama berhaji. Kemungkinan bakteri tertular karena jamaah memakai fasilitas bersama seperti kamar mandi dan tempat berwudhu. Selanjutnya jamaah menggunakan bis yang sama menuju Mekkah selama 8 jam. Kemungkinan bakteri tertular pada kondisi ini yaitu melalui keringat pada kulit yang bersentuhan maupun bakteri tak terlihat secara kasat mata yang menempel pada bangku bis. Pemodelan dilakukan berdasarkan asumsi nomor 1 sampai 3. Kondisi kemungkinan penularan ini digambarkan dalam skema berikut.

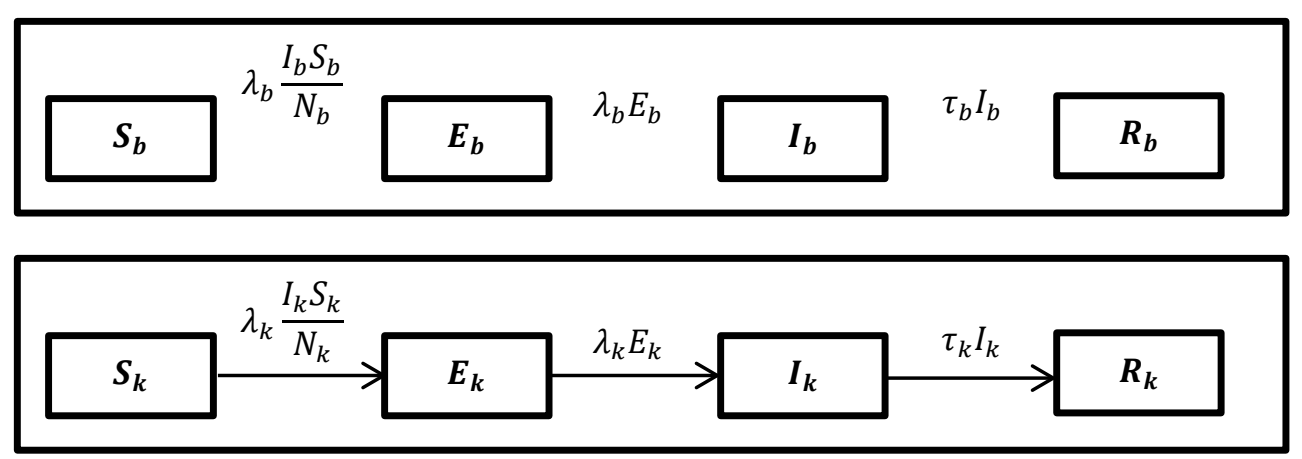

Gambar 1. Skema penularan periode 1 untuk negara besar dan negara kecil selama 7 hari di Madinah tanpa aturan vaksin

\subsubsection{Kasus Periode 2}

Pemodelan pada kasus periode II dilakukan berdasarkan asumsi nomor 2 sampai 4. Kegiatan-kegiatan yang dilakukan selama 18 hari pada periode ini antara lain:

1) Ibadah Ibadah Thawaf, dimana karena jamaah harus berdesak-desakan sehingga kemungkinan penularan bakteri dapat terjadi melalui keringat, bersin, maupun batuk.

2) Mengambil air zam-zam melalui pemakaian fasilitas kran air bersama. 
3) Bermalam di Mina untuk melakukan lempar jumroh. Setiap jamaah haji harus mengumpulkan kerikil sebanyak 10-70 butir. Karena kondisi yang panas dan lokasi yang berdebu, maka penularan bakteri dapat terjadi melalui keringat, air liur, bersin, maupun batuk.

4) Sa'i.

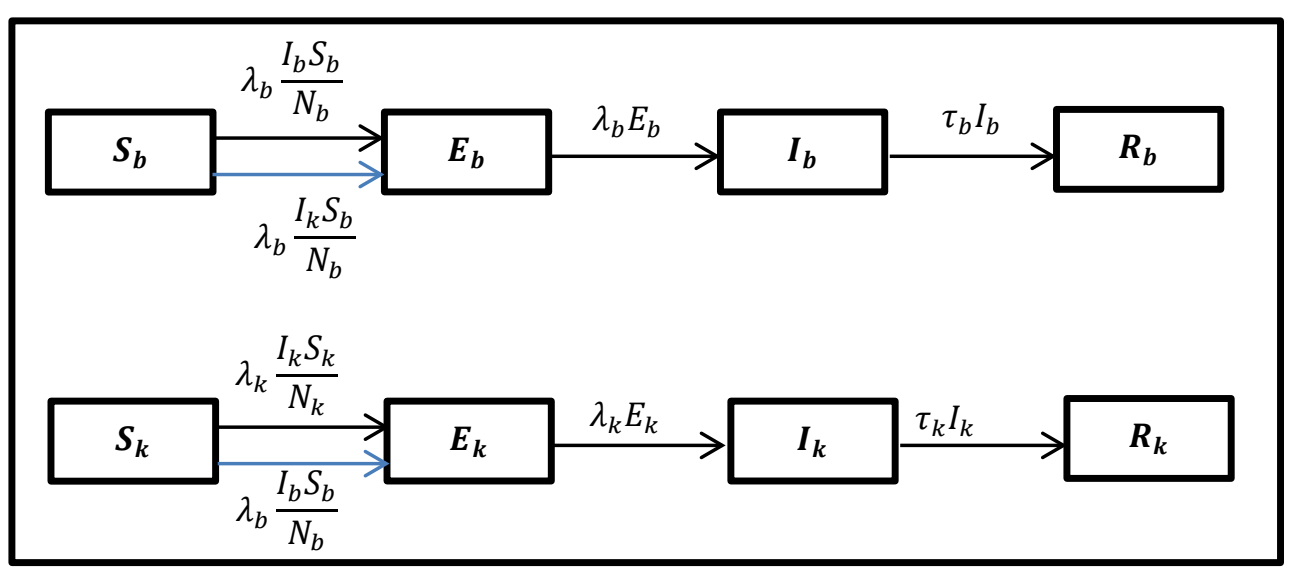

Gambar 2. Skema penularan periode 2 untuk negara besar dan negara kecil selama 18 hari di Mekkah dan Madinah tanpa aturan vaksin

\subsubsection{Model Matematika dan Simulasi Data Tanpa Aturan Vaksin}

Berdasarkan skema penularan pada Gambar 1 dan Gambar 2, dapat dituliskan model matematika masing-masing periode untuk negara kecil dan negara besar seperti pada tabel berikut.

Tabel 1. Model matematika kasus periode 1 dan 2 tanpa aturan vaksin

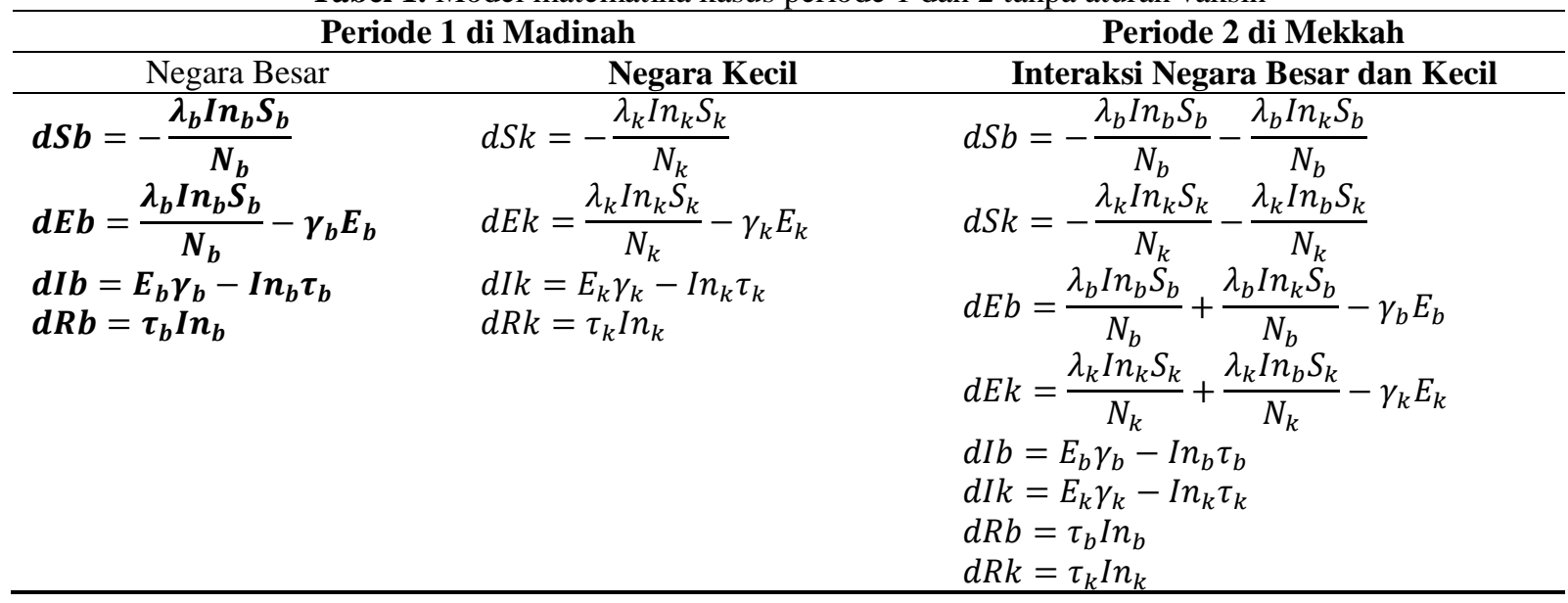

Selanjutnya dilakukan simulasi menggunakan software Maple 18 untuk melihat laju penularan tanpa aturan vaksin. Hasil simulasi ditampilkan dalam Gambar 3.

Pada negara kecil, laju penularan yang tinggi mengakibatkan populasi terinfeksi bertambah namun tingkat kesembuhan kecil. Hal ini menegaskan perlunya penetapan aturan vaksin. Laju populasi penduduk sehat berkurang karena ada laju penularan jamaah negara besar dengan populasi haji lebih banyak dibanding negara kecil pada ruang interaksi yang sama akan lebih cepat, karena interakasinya lebih padat sehingga bakteri mudah menular. Infeksi semakin tinggi sementara laju penyembuhan kecil. Karena periode pertama hanya 7 hari, laju penduduk sehat cenderung konstan. Laju penularan yang cukup besar dan cepat mengakibatkan adanya infeksius dan berdampak pada berkurangnya penduduk sehat. Belum ditetapkan aturan vaksinasi pada periode ini mengakibatkan laju penyembuhan penderita sangat kecil. Hal ini menjadi alasan aturan wajib vaksin harus dilakukan. Sedangkan pada kasus periode 2, interaksi yang semakin tinggi antar warga jamaah beda negara dapat mengakibatkan terjadi penularan dan infeksi semakin tinggi. Hal itu terlihat pada gambar 4 sesuai hasil simulasi menggunakan software Maple 18. 

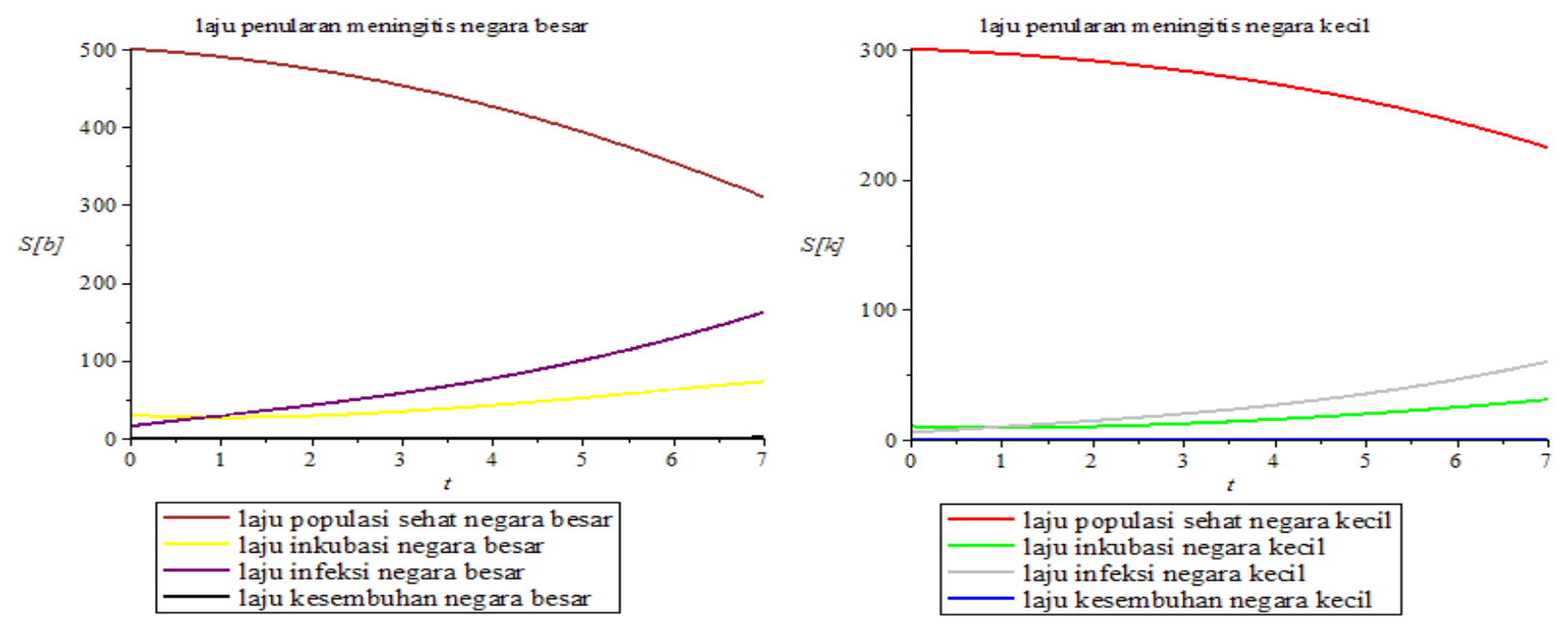

Gambar 3. Hasil simulasi data kasus periode 1 untuk negara besar dan negara kecil di Madinah tanpa aturan vaksin
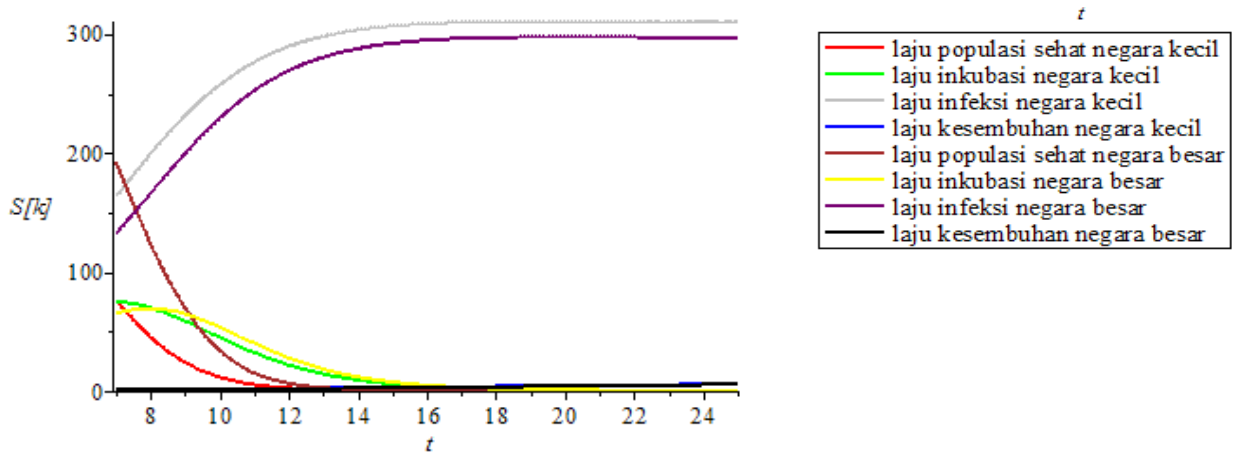

Gambar 4. Hasil simulasi data kasus periode 2 untuk negara besar dan kecil di Mekkah dan Madinah tanpa aturan vaksin

\subsection{Pemodelan dengan Aturan Vaksinasi}

Adanya peningkatan infeksi pada periode haji dari tahun ke tahun membuat pemerintah dan pihak imigrasi menetapkan aturan wajib vaksin bagi setiap orang yang hendak berhaji, dengan tujuan mereduksi jumlah kasus penularan. Sama halnya dengan pemodelan sebelum ditetapkan aturan vaksin, kasus penularan dibagi ke dalam dua periode, dan terjadi interaksi antara jamaah negara besar dan kecil, hanya saja sudah ada intervensi vaksin.

\subsubsection{Kasus Periode 1}

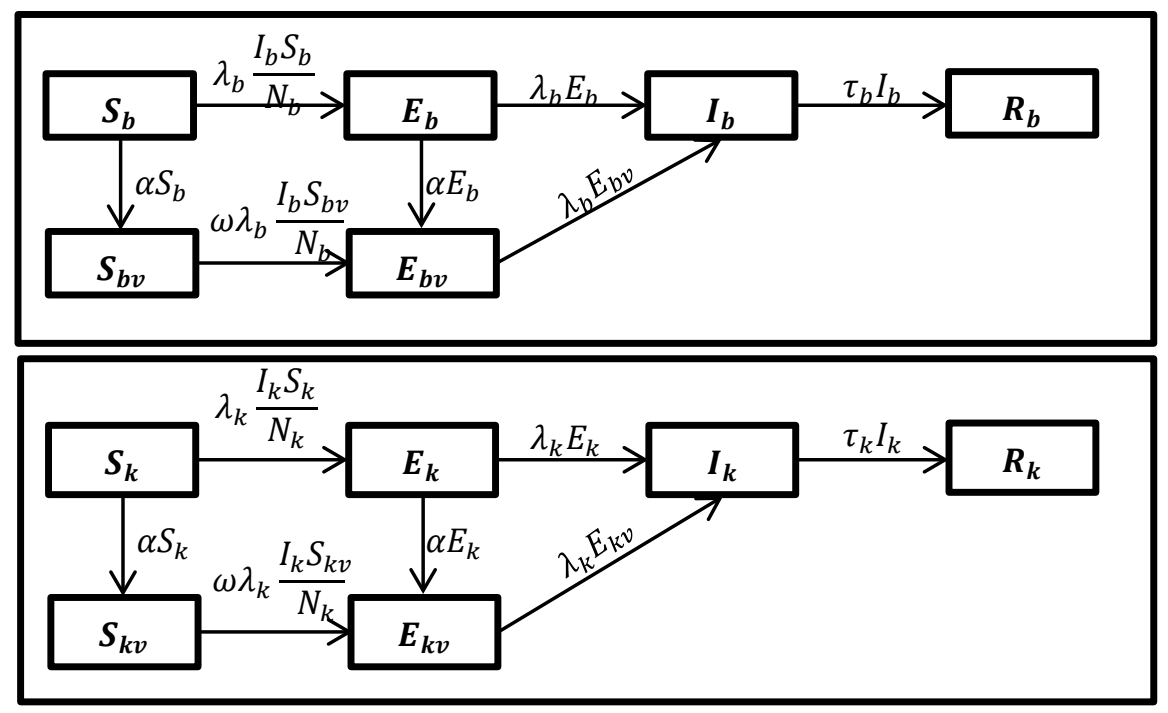

Gambar 5. Skema penularan periode 1 untuk negara besar dan negara kecil selama 7 hari di Madinah dengan aturan vaksin 


\subsubsection{Kasus Periode 2}

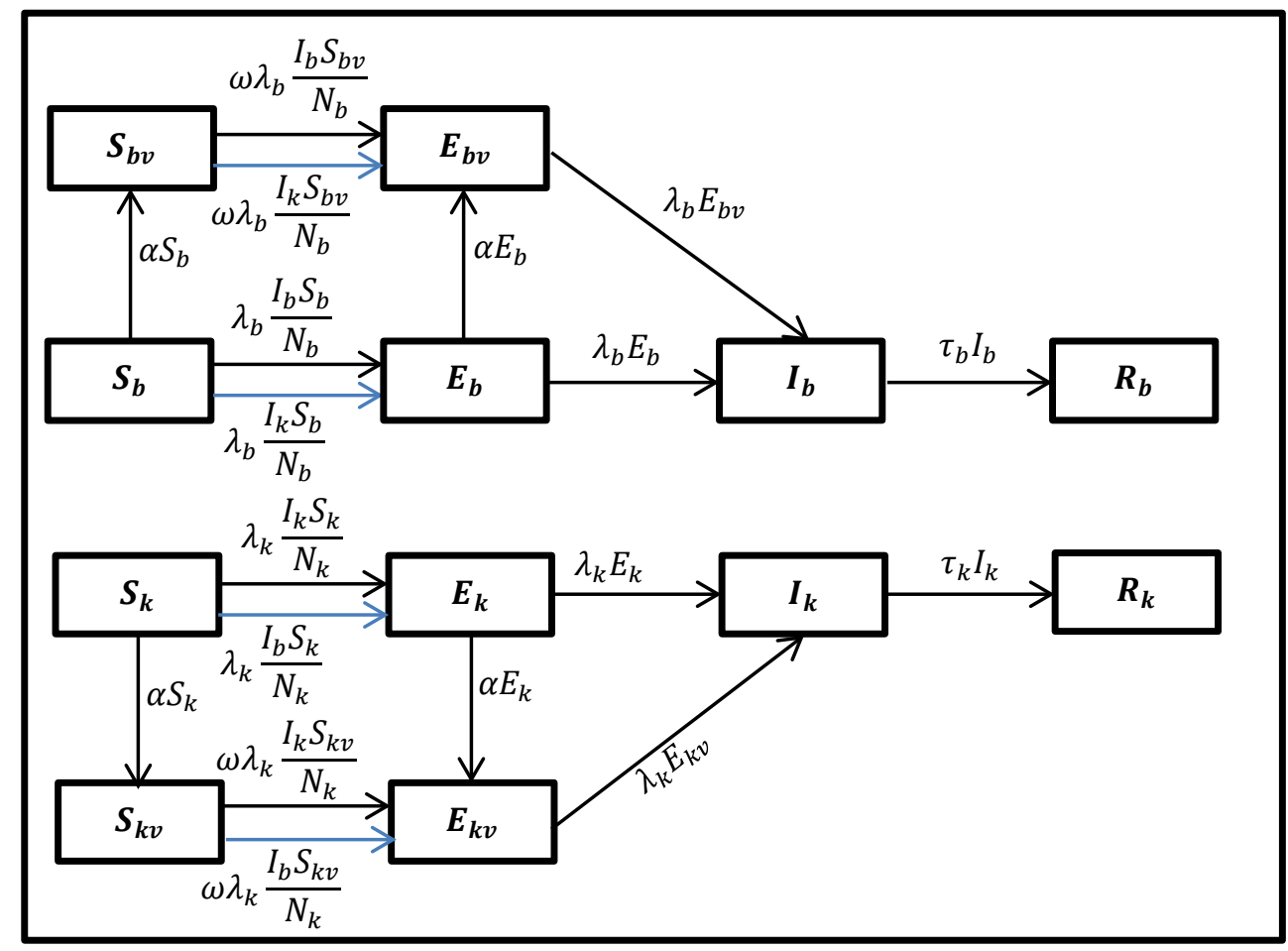

Gambar 6. Skema penularan periode 2 untuk negara besar dan negara kecil selama 18 hari di Mekkah dan Madinah dengan aturan vaksin

\subsubsection{Model Matematika dan Simulasi Data dengan Aturan Vaksin}

Berdasarkan skema penularan pada Gambar 5 dan Gambar 6, dapat dituliskan model matematika masing-masing periode untuk negara kecil dan negara besar seperti pada tabel berikut.

Tabel 2. Model matematika kasus periode 1 dan 2 dengan aturan vaksin

\begin{tabular}{|c|c|}
\hline \multicolumn{2}{|c|}{ Periode I di Madinah } \\
\hline Negara Kecil & Negara Besar \\
\hline$d S k=-\frac{\lambda_{k} I n_{k} S_{k}}{N_{k}}-\alpha S_{k}$ & $d S b=-\frac{\lambda_{b} \operatorname{In} n_{b} S_{b}}{N_{b}}-\alpha S_{b}$ \\
\hline$d S k v=\alpha S_{k}-\frac{\omega \lambda_{k} I n_{k} S_{k v}}{N_{k}}$ & $d S b v=\alpha S_{b}-\frac{\omega \lambda_{b} I_{b} S_{b v}}{N_{b}}$ \\
\hline$d E k=\frac{\lambda_{k} I n_{k} S_{k}}{N_{k}}-\gamma_{k} E_{k}-\alpha E_{k}$ & $d E b=\frac{\lambda_{b} I n_{b} S_{b}}{N_{b}}-\gamma_{b} E_{b}-\alpha E_{b}$ \\
\hline $\begin{array}{r}d E k v=\alpha E_{k}+\frac{\omega \lambda_{k} I n_{k} S_{k}}{N_{k}} \\
-\gamma_{k} E_{k v} \\
d I k=E_{k} \gamma_{k}+E_{k v} \gamma_{k}-I n_{k} \tau_{k} \\
d R k=\tau_{k} I n_{k}\end{array}$ & $\begin{array}{l}d E b v=\alpha E_{b}+\frac{\omega \lambda_{b} I n_{b} S_{b}}{N_{b}}-\gamma_{b} E_{b v} \\
d I b=E_{b} \gamma_{b}+E_{b v} \gamma_{b}-\operatorname{In}_{b} \tau_{b} \\
d R b=\tau_{b} I n_{b}\end{array}$ \\
\hline
\end{tabular}

Selanjutnya dilakukan simulasi menggunakan software Maple 18 dari data yang diperoleh untuk melihat laju penularan dengan aturan vaksin. Hasil simulasi ditampilkan dalam gambar berikut. 

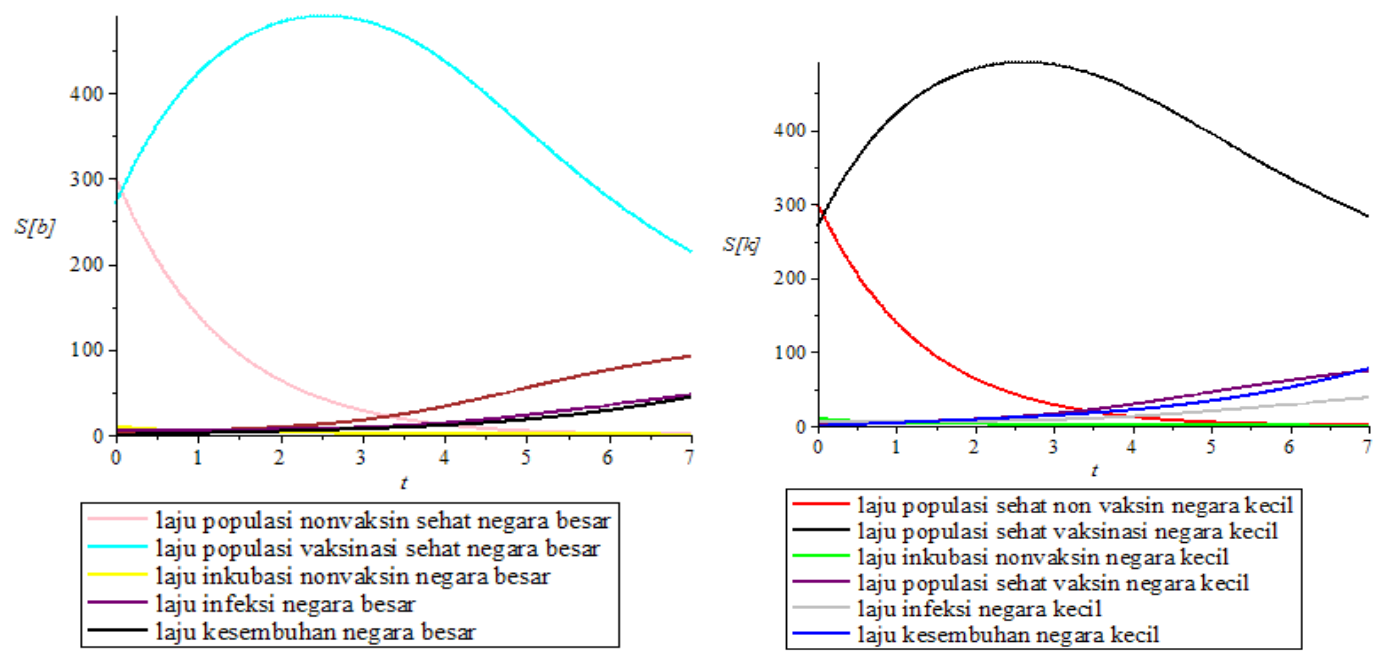

Gambar 7. Hasil simulasi data kasus periode 1 untuk negara besar dan negara kecil di Madinah dengan aturan vaksin
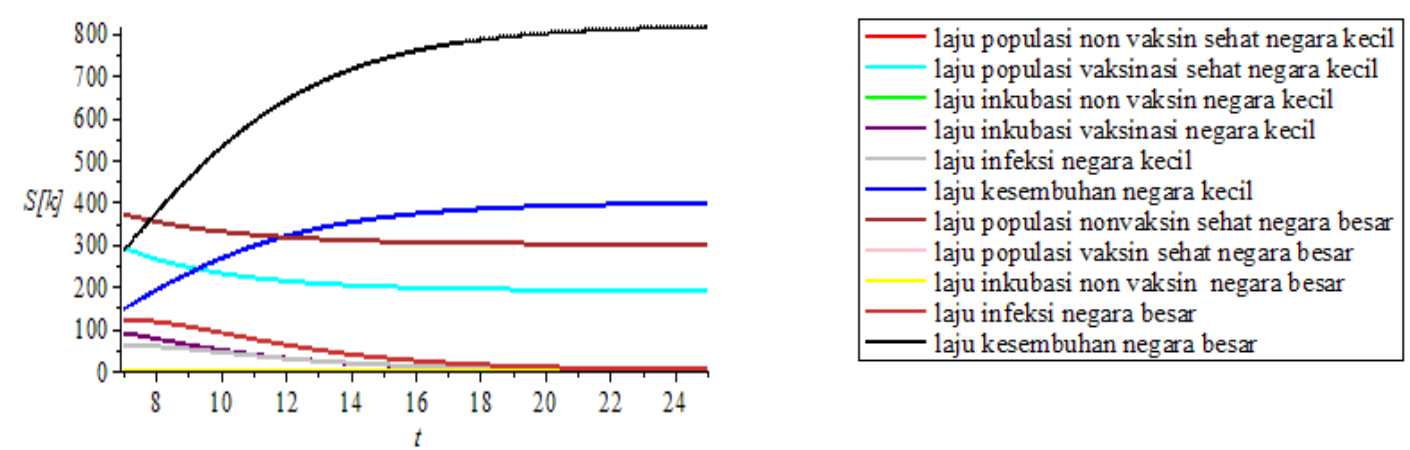

Gambar 8. Hasil simulasi data kasus periode 2 untuk negara besar dan kecil

di Mekkah dan Madinah dengan aturan vaksin

Dari Gambar 8 terlihat bahwa laju pertumbuhan inkubasi pada negara besar lebih cepat daripada laju inkubasi pada negara kecil.

\section{Kesimpulan}

Berdasarkan hasil analisis data dan pembahasan maka dapat diambil kesimpulan sebagai berikut:

1) Dari hasil simulasi data terlihat bahwa banyak atau sedikitnya jamaah yang terinfeksi sangat mempengaruhi kecepatan laju penyebaran meningitis. Hal ini disebabkan virus meningitis terjangkit melalui kontak langsung.

2) Persentase laju penyebaran sebelum vaksinasi sangat cepat daripada setelah vaksinasi, hal ini yang menyebabkan pemerintah Arab Saudi secara ketat memberlakukan peraturan vaksinasi jamaah haji sebelum memasuki wilayah Arab Saudi.

\section{Daftar Pustaka}

[1] S. Yezli, A. Wilder-Smith and A. Bin Saaed, "Carriage of Neisseria meningitidis in the Hajj and Umrah Mass Gatherings,” International Journal of Infectious Diseases, pp. 65-70, 2015.

[2] S. Yezli, A. M. Assiri, R. F. Alhakeem, A. Trkistani and B. Alotaibi, "Meningococcal Disease During the Hajj and Umrah Mass Gatherings,” International Journal of Infectious Diseases, pp. 60-64, 2016.

[3] F. Brauer and C. Castilo-Chavez, Mathematical Models in Population Biology and Epidemiology, Second Edition, New York, USA: Springer Science-Business Media, 2012. 